\title{
Grading of joint indices for severity reflects better the burden of joint disease and its impact on child's well-being in juvenile idiopathic arthritis (JIA)
}

\author{
C Visconti*1, A Ravelli², C Klersy ${ }^{1}$, S Lanni ${ }^{1}$, S Caimmi ${ }^{1}$, E Borali ${ }^{1}$, \\ V Muratore ${ }^{1}$ and S Magni-Manzoni ${ }^{1}$
}

Address: ${ }^{1}$ Dep Pediatrics, Fondazione IRCCS Policlinico San Matteo, Pavia, Italy and ${ }^{2}$ Pediatria II, IRCCS G. Gaslini, Genova, Italy

* Corresponding author

from I5th Paediatric Rheumatology European Society (PreS) Congress

London, UK. 14-17 September 2008

Published: 15 September 2008

Pediatric Rheumatology 2008, 6(SuppI I):PIII doi:I0.I I86/I546-0096-6-SI-PI I I

This abstract is available from: http://www.ped-rheum.com/content/6/SI/PIII

(c) 2008 Visconti et al; licensee BioMed Central Ltd.

\section{Background and aim}

The severity of joint disease in JIA can be quantified by counting the number of joints with swelling, tenderness/ pain on motion, and restricted motion, and by calculating, through these parameters, the number of active joints (NAJ). Alternatively, a global articular severity score (GASS) can be obtained by grading symptoms in each joint and summing the scores obtained in all joints. Although the former method is currently preferred, it is unclear which method is more advantageous to capture the impact of joint disease on child's health and wellbeing. We aimed to compare the ability of NAJ and GASS to capture the impact of joint disease on child's health and well-being by assessing their correlation with physician's, parent's and patient's subjective ratings and functional ability assessment.

\section{Methods}

Thirty-four JIA patients underwent a standardized joint assessment and had both NAJ and GASS calculated. Correlation of NAJ and GASS with physician's, parent's and patient's global rating, parent's and patient's pain rating, and functional ability assessment through the Juvenile Arthritis Functionality Scale (JAFS) was evaluated using Spearman's correlation coefficient.

\section{Results}

Table 1 shows Spearman's correlations between global joint scores and other JIA outcome parameters.

\section{Conclusion}

All correlations were greater for the GASS than for the NAJ, suggesting that the GASS reflects better the burden of joint disease and its impact on child's well-being. 
Table I: Spearman's correlations between global joint scores and other JIA outcome parameters.

\begin{tabular}{llllllll}
\hline & MD global & Parent global & Patient global & Parent pain & Patient pain & JAFS parent & JAFS patient \\
\hline NAJ & 0.49 & 0.18 & 0.17 & 0.24 & 0.35 & 0.43 & 0.35 \\
GASS & 0.69 & 0.42 & 0.38 & 0.50 & 0.5 I & 0.52 & 0.60 \\
\hline
\end{tabular}

Publish with Bio Med Central and every scientist can read your work free of charge

"BioMed Central will be the most significant development for disseminating the results of biomedical research in our lifetime. " Sir Paul Nurse, Cancer Research UK

Your research papers will be:

- available free of charge to the entire biomedical community

- peer reviewed and published immediately upon acceptance

- cited in PubMed and archived on PubMed Central

- yours - you keep the copyright 